Issued by Sandia National Laboratories, operated for the United States Department of Energy by Sandia Corporation.

NOTICE: This report was prepared as an account of work sponsored by an agency of the United States Government. Neither the United States Government, nor any agency thereof, nor any of their employees, nor any of their contractors, subcontractors, or their employees, make any warranty, express or implied, or assume any legal liability or responsibility for the accuracy, completeness, or usefulness of any information, apparatus, product, or process disclosed, or represent that its use would not infringe privately owned rights. Reference herein to any specific commercial product, process, or service by trade name, trademark, manufacturer, or otherwise, does not necessarily constitute or imply its endorsement, recommendation, or favoring by the United States Government, any agency thereof, or any of their contractors or subcontractors. The views and opinions expressed herein do not necessarily state or reflect those of the United States Government, any agency thereof, or any of their contractors.

Printed in the United States of America. This report has been reproduced directly from the best available copy.

Available to DOE and DOE contractors from Office of Scientific and Technical Information

P.O. Box 62

Oak Ridge, TN 37831

Prices available from (703) 605-6000

Web site: http://www.ntis.gov/ordering.htm

Available to the public from

National Technical Information Service

U.S. Department of Commerce

5285 Port Royal Rd

Springfield, VA 22161

NTIS price codes

Printed copy: A03

Microfiche copy: A01

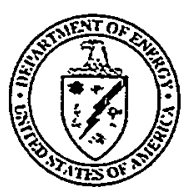




\section{DISCLAIMER}

\section{Portions of this document may be illegible in electronic image products. Images are produced from the best available original document.}


SAND99-2610

Unlimited Release

Printed October 1999

\title{
DEVELOPMENT OF A SPECIAL APPLICATION COILED TUBING APPLIED PLUG FOR GEOTHERMAL WELL CASING REMEDIATION
}

\author{
G.E. Staller, S.D. Knudsen, and A.R. Sattler \\ Geothermal Research Department \\ Sandia National Laboratories \\ P.O. Box 5800 \\ Albuquerque, NM 87185-1033
}

\begin{abstract}
Casing deformation in producing geothermal wells is a common problem in many geothermal fields, mainly due to the active geologic formations where these wells are typically located. Repairs to deformed well casings are necessary to keep the wells in production and to occasionally enter a well for approved plugging and abandonment procedures. The costly alternative to casing remediation is to drill a new well to maintain production and/or drill a well to intersect the old well casing below the deformation for abandonment purposes. The U.S. Department of Energy and the Geothermal Drilling Organization sponsored research and development work at Sandia National Laboratories in an effort to reduce these casing remediation expenditures. Sandia, in cooperation with Halliburton Energy Services, developed a low cost, bridge-plug-type, packer for use in casing remediation work in geothermal well environments. This report documents the development and testing of this commercially available petal-basket packer called the Special Application Coiled Tubing Applied Plug (SACTAP).
\end{abstract}




\section{Acknowledgments}

The authors would like to acknowledge the contributions of Mr. Jamie Terrell, manager of the Physics and Chemistry Laboratory, Halliburton Energy Services, Fort Worth, TX, during the design, development, and laboratory testing of the SACTAP. We would also like to acknowledge the field test support provided by the Halliburton Energy Services coiled tubing crews in Midland, TX under the supervision of Mr. Don Rodgers. Finally, the authors are indebted to Mr. Doug Love, Halliburton Energy Services, Midland, TX, for his oversight and leadership during field test operations.

This work was sponsored by the U. S. Department of Energy, Office of Geothermal Technologies. 


\section{TABLE OF CONTENTS}

Page

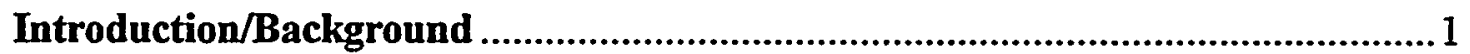

Technical Requirements and Product Search ....................................................

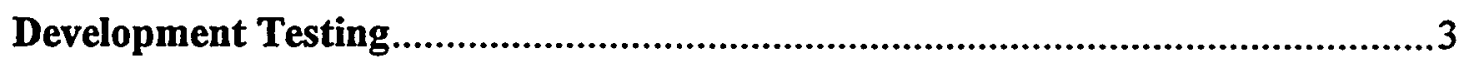
A.) Development Testing at the Fort Worth, TX Facility 3
B.) First Field Test at the Midland, TX Facility .................................6
C.) Modification Tests at the Fort Worth, TX Facility .........................9
D.) Second Field Test at the Midland, TX Facility...............................10

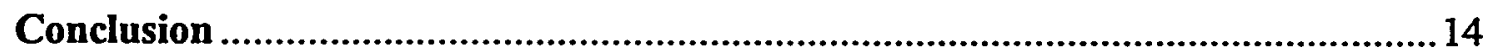

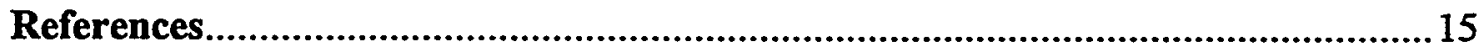

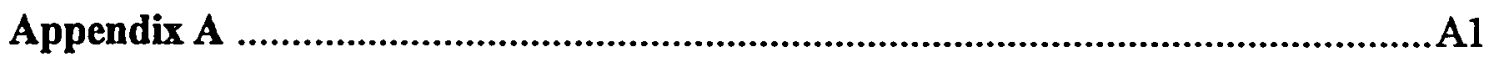




\section{Introduction/Background}

Geothermal wells are commonly drilled in harsh geological formations where geologic activity is prevalent. Steam and hot water production wells, in this environment, are exposed to recurrent geologic activities that often result in formation shear or subsidence loads being applied to the well casings. These progressive loads often cause the casing, at certain depths, to be deformed severely enough to reduce well production efficiency and/or restrict or prevent tool access into the well below the affected zones. If the casing is not satisfactorily maintained, worsening deformations can lead to costly well repairs or result in premature plugging and abandonment of a producing well.

The Unocal Corporation, Division of Geothermal \& Power Operations, installed and maintained geothermal production wells at The Geysers Geothermal Field near Santa Rosa, CA. These wells have since been purchased by Calpine Corporation. As a result of normal inspections on the wells in this field, over 50 have been identified with deformed well casings. At the request of Unocal, a two-phase Geothermal Drilling Organization (GDO) proposal was prepared by Unocal and Sandia National Laboratories ${ }^{1}$ to address the casing deformation and remediation issue. As part of Phase I of this proposal, Sandia was asked to utilize the Drillable Straddle Packer ${ }^{2}$ (DSP) design as a bridge plug for casing remediation work. The DSP bridge plug was to be placed in the well, below the deformation in the casing. This plug was to support a sand and cement plug until the cement properly cured. This DSP/cement plug combination would in turn support the drilling fluids used during the casing repair operations. The DSP was developed by Sandia, as an inexpensive, high temperature packer for lost circulation treatment in open hole geothermal wells. Although the DSP met the temperature requirements and could expand to fill the casing, after passing through the deformation, some redesign and testing of the protective shroud, the bag packaging technique, and the deployment procedures was required before the DSP could be used in this type of bridge plug application.

The work schedule for this project was prepared by Unocal. Their schedule required a rapid response to Phase I of the GDO proposal and this left insufficient time for redesign of the DSP. Sandia recommended looking for a commercial packer that could be purchased off-the-shelf and used immediately or could be quickly modified to meet project requirements.

\section{Technical Requirements and Product Search}

Technical specifications for the bridge plug were prepared by Unocal and Sandia and are as follows:

1. Well environment - steam.

2. Peak well temperature $-450^{\circ} \mathrm{F}$.

3. Maximum well pressure $-200 \mathrm{psi}$.

4. Well flow conditions - shut-in (no flow).

5. Casing restriction - minimum I.D. 4.50". 
6. Casing specification where plug will be deployed - 11-3/4" (10.88" I.D. X .435" Wall), 54\#/ft, Grade K-55 steel. (Note: This will require a plug expansion ratio of $2.7: 1$ to pass a $4.00^{\prime \prime} \mathrm{OD}$ plug through the $4.50^{\prime \prime} \mathrm{ID}$ deformation, then fill the 10.88 " casing ID.)

7. The plug must support $50^{\prime}$ of dry sand followed by a $200^{\prime}$ pour of cement.

8. The plug should be retrievable or drillable.

Based on these requirements, a product search was initiated by Sandia for a suitable packer.

Prior oil field experience by Sandia staff led to an investigation into the status of the Gearhart-Owen Industries, Inc. (GO) Thru-Tubing Bridge Plugs. These plugs could be set in casings on wireline, through a small aperture or tubing, and could support sand and cement to form a casing plug similar to the plug needed for the casing remediation work. However, the $\mathrm{GO}$ bridge plugs were produced for use in small diameter $(<9-5 / 8 ")$ casings and at lower temperatures than those encountered in The Geysers wells. The GO thrutubing bridge plugs were sold under part numbers 51-5143-00 through 51-5143-08. These plugs are no longer commercially available, however, the inventor of the original GO bridge plug, Mr. Jamie Terrell is employed by Halliburton Energy Services (HES). Mr. Terrell and HES hold the license to produce and sell the GO bridge plugs. After reviewing the technical specifications for the casing remediation bridge plug, Mr. Terrell, indicated that, with some design changes and proof testing, a suitable plug could be produced to meet our design requirements and time schedule.

Unocal and Sandia contacted several inflatable packer manufactures in an effort to identify a commercial off-the-shelf inflatable packer for this application. A visit was made to TAM International, Inc., Houston, TX by both Sandia and Unocal staff to review inflatable packer designs and discuss packer requirements for casing remediation. The main limitation to using inflatable packers for this project was the high temperatures that the packer elastomer encounters in The Geysers wells. The reliability of the inflatable elements is related to the expansion ratio and peak working temperature. As stated in the technical requirements, an expansion ratio of approximately $2.7: 1$ is needed and at this ratio, combined with a peak well temperature of $450^{\circ} \mathrm{F}$, TAM did not recommend using their inflatable packer for casing remediation. However, a test was arranged by Unocal and TAM to test a new elastomer that could perhaps meet project requirements. This test was conducted at Schlumberger Inc.'s test laboratory in Sugarland, TX. Test results were inconclusive and schedule requirements did not permit further evaluation and testing of the new packer elastomer for use on this project.

A meeting to discuss the casing remediation project and select a packer design was held by Unocal at their offices in Santa Rosa, CA on 4/3/98. Attendees included staff from Sandia, Brookhaven National Laboratory, HES, Baker Oil Tools, Calpine, and Bill Livesay, a Sandia consultant. The modified HES thru-tubing bridge plug was selected as the best option for a casing plug based on its ability to meet design specifications as well as project schedules. It was also determined that the most desirable method to deploy this plug would be on coiled tubing. This would save time and money since dump bailer runs 
for emplacing the sand and/or cement on the bridge plug could be eliminated. Sandia initiated a contract with HES, Fort Worth to develop and test a modified thru-tubing bridge plug that would meet project requirements. The contract specified that the plug should be deployed on coiled tubing, set in the casing using nitrogen gas, and meet all other specifications previously defined for the casing remediation plug.

\section{Development Testing}

\section{A.) Development Testing at the Fort Worth, TX Facility}

The HES facilities in Ft. Worth are used to assemble and test various drilling tools and equipment prior to field use. Jamie Terrell's facility, at this site, is designed to assemble and test chemical cutter tools. HES has been considering manufacturing and marketing the old GO bridge plugs through this facility. Mr. Terrell is the primary contact for production and sales of these plugs. Our need for a modified GO plug allowed him to utilize both his facility and the local manufacturing contractors to produce and test the casing remediation bridge plug.

The thru-tubing bridge plug (BP) consists of a collapsible metal petal basket and four collapsible centralizer support dogs all attached to a center support shaft. The petal basket is covered with a high temperature fire retardant material called Nomex. The Nomex cover helps to prevent sand from falling through the voids between the petal basket petals. The support dogs contain six legs that are deployed by springs that force the legs out against the casing wall. When deployed the support dogs secure the BP in the casing by digging into the casing wall with high strength steel tips on the end of each of the six legs. The support dog assemblies are positioned so two sets support the BP against downward movement in the well and two sets prevent upward movement, see Figure 1. Likewise, the petal basket is spring loaded to force it open and out against the casing wall when deployed. A shroud or sleeve around the outside of the BP retains and protects the dogs and petal basket in their folded/closed position until the shroud is removed for BP deployment, after insertion in a casing.

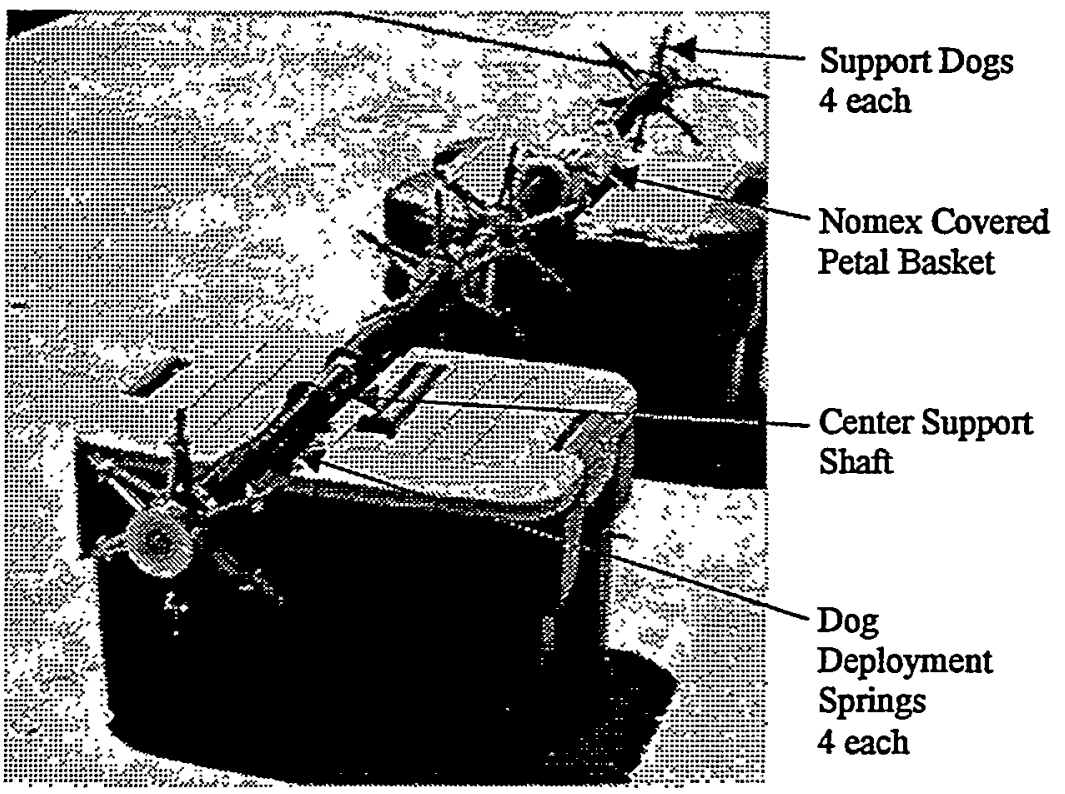

Figure 1 - BP Assembly in Opened Configuration 


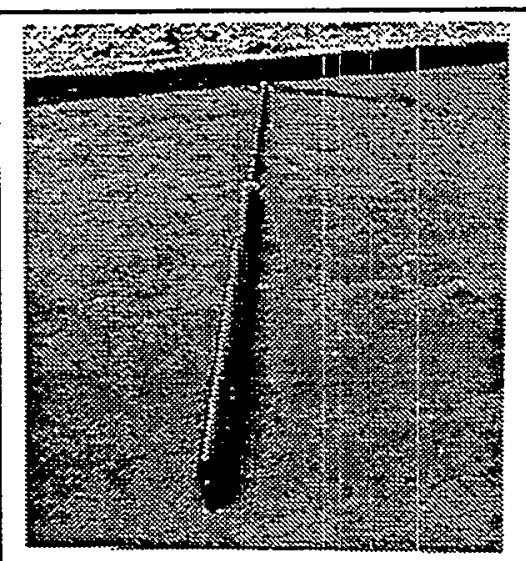

Figure 2 - Shroud Assembly
To test the shroud/sleeve operation, the mechanism was set up outdoors on a concrete pad. Only the shroud mechanical action (no BP inside the shroud) was tested. To operate the shroud it was connected to a domestic water supply with a garden hose. The water pressure was used to operate the shroud. This simulated shroud operation with coiled tubing and nitrogen gas, but permitted a safer low-pressure hydrostatic test. The shroud assembly is shown in Figure 2. When pressure is applied to the inside of the shroud support/slide tube, a piston that is attached to the shroud is forced up around the outside of the support tube. As the piston and shroud slide up this tube, the BP is uncovered, exposing the dogs that secure the center shaft and the petal basket to the casing wall. The BP would be set in a vertical orientation in a casing, although these shroud tests were done in a horizontal position. The shroud mechanism operated as intended and slid along the support/slide shaft in a steady smooth movement.

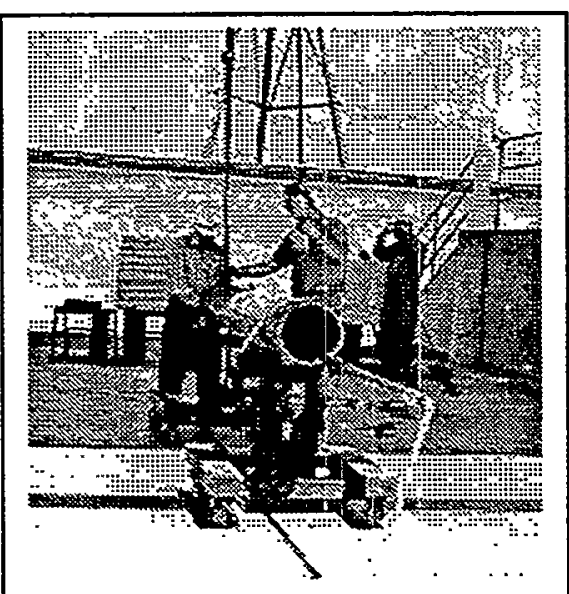

Figure 3 - BP Assembly in Casing

A second test was conducted to confirm the operation of the shroud with the BP inside and to test the BP's mechanical strength for supporting sand and cement in a casing. A ten foot length of 11-3/4", 54\#/ft, grade $\mathrm{K}-55$ steel casing was purchased. The casing was positioned horizontally on two dollies for BP installation. The BP was installed in the shroud mechanism and this assembly was then positioned inside the casing, as shown in Figure 3. The shroud was again deployed with domestic water pressure, but because the assembly was not centered in the casing during deployment (it was lying on the bottom of the horizontal casing), some minor post-deployment adjustment was required. After adjustment, all four dogs and the petal basket were verified to be in their proper position. The casing was then to be positioned vertically for load testing. However, the BP was set near the bottom end of the casing and any movement during load testing could cause the bottom dogs to slide out of the casing. To prevent this from occurring, an additional 12" length of casing was tack welded to the bottom end of the test casing. Care was required to keep from overheating the bottom BP dogs during this welding operation. After this extension was attached to the test casing, the entire assembly (casing with BP inside) was positioned vertically using the test facility bridge crane and secured to an existing concrete retaining wall, as shown in Figure 4.

To verify that the sand load on the BP was acceptable, we poured 200 pounds $(-3 \mathrm{ft}$. of depth) of sand directly onto the petal basket. A BP deflection of less than 0.25 " was 


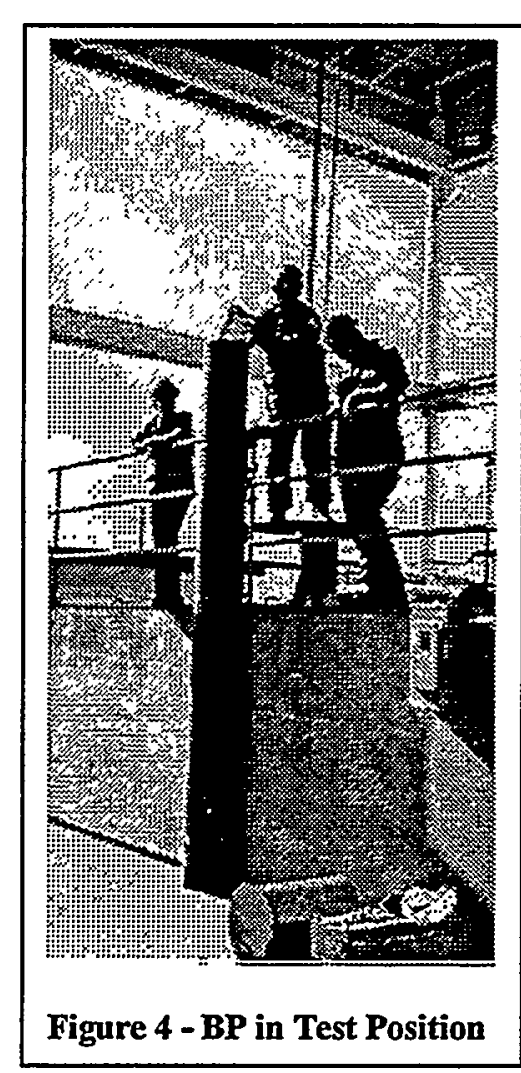
density of cement is $\sim 16 \mathrm{\# /gal}$ or 1 psi per foot of depth, and the cross-sectional area of the casing $\mathrm{ID}$ is $\sim 93 \mathrm{sq}$. in., then the 50 ' of cement will apply approximately 4650 pounds of additional load to the BP.

A peak load of 5000 pounds, as measured with our load cell, was applied to the top of the sand using the hydraulic jack. When the load was applied, a total BP deflection of 0.124 " was measured with an indicator gage attached to the base of the hydraulic jack. Knowing that the sand bridged the load to the casing wall, a second load test was conducted to verify the maximum load that could be applied to the BP without sand. The test assembly was again positioned on the dollies horizontally. The HES load frame was removed from the top of the casing and secured to the bottom so the BP could be pulled from the bottom side. A yoke was attached to the bottom of the BP center support shaft. A load cell was attached to this yoke and to a hydraulic cylinder used for pulling. The hydraulic cylinder was in turn attached to the load frame. A photograph of this set up is shown in Figure 6. With the hydraulic cylinder, we applied a tensile load of 6000 pounds to the BP with no detectable movement of the BP inside the casing. This is an equivalent load of 64 feet of cement being applied directly to the BP without the sand bridging the load to the casing. A pull test to failure was not done since these loads were considered to be in excess of those expected during casing remediation applications. 


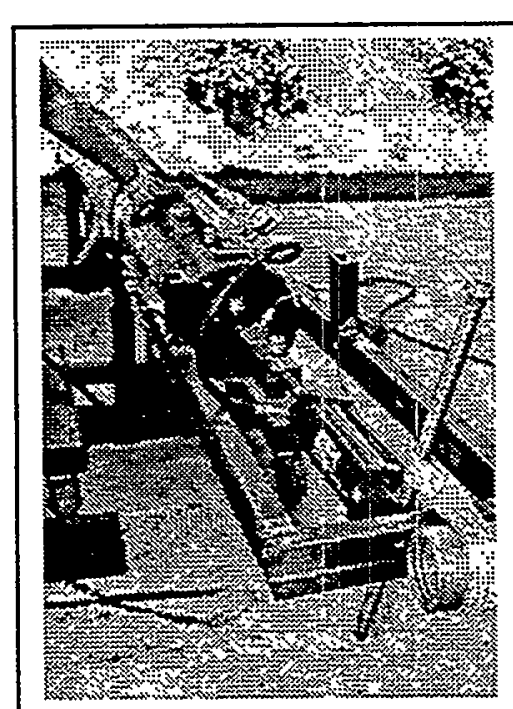

Figure 6 - Pull Test Setup

During testing, concerns were raised about pumping sand through $2^{\prime \prime}$ diameter coiled tubing into a hot geothermal well. The main fear was that the flowing sand would dry out and bridge off inside the coiled tubing before it could be positioned on the BP petal basket. It was decided to change the BP requirements to eliminate pumping the sand through the coiled tubing and instead apply $10^{\prime}$ of cement directly onto the petal basket. After this $10^{\prime}$ column of cement hardened in the casing, an additional $190^{\prime}$ of cement could then be applied with another coiled tubing run. The State of California requires a 200' plug if a well is to be abandoned. To test the bridge plug with cement on the petal basket, instead of sand, several lab tests were conducted. A BP petal basket with the Nomex cloth bag was deployed in a test casing and cement was poured onto the basket. Only a small amount of cement flowed through the basket. The cloth covered petal basket should block and hold the cement for a sufficient amount of time to allow a $10^{\prime}$ column to harden. To test this cement-only BP, it was decided to utilize the previously deployed BP inside the test casing containing the sand. The sand was removed and an additional section of casing was welded to the original casing to extend its length. This length extension was required so a $10^{\prime}$ column of cement could be installed from the BP petal basket to the top of the casing. As shown in Figure 7, the test casing was again mounted vertically. Cement was pumped into the top until the casing was full. Only a small amount of water was observed below the BP and no cement filtered past the petal basket. After the cement cured the casing was positioned horizontally and cut in half along its length, as shown in Figure 8. After cutting the casing, it was noted that not all of the sand from the first test had been removed. However, the small amount of sand

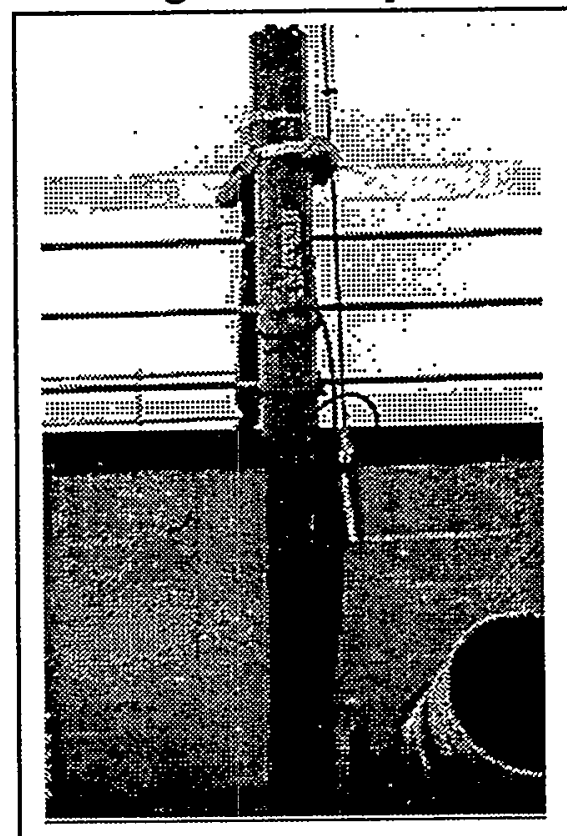

Figure 7 - Cement Test Setup

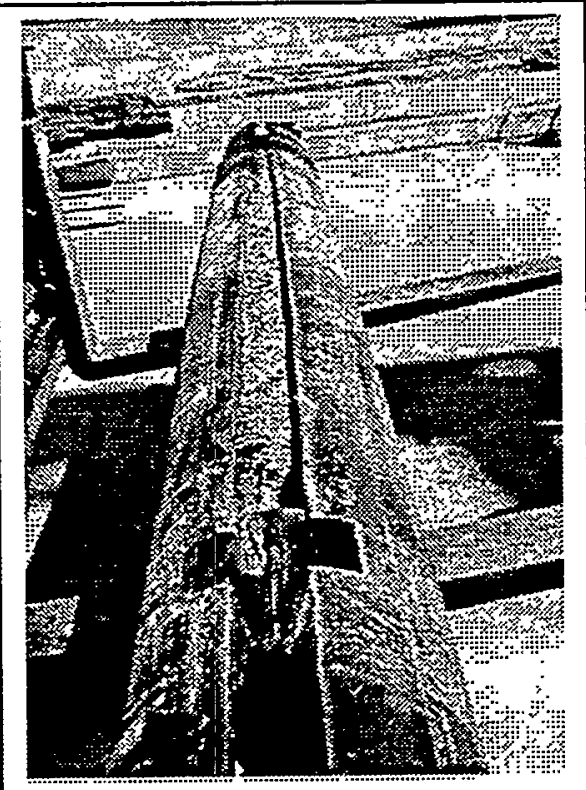

Figure 8 - Cement Test Cut Casing 
left in the casing did not appear to adversely impact these test results and placing the cement directly onto the petal basket was approved.

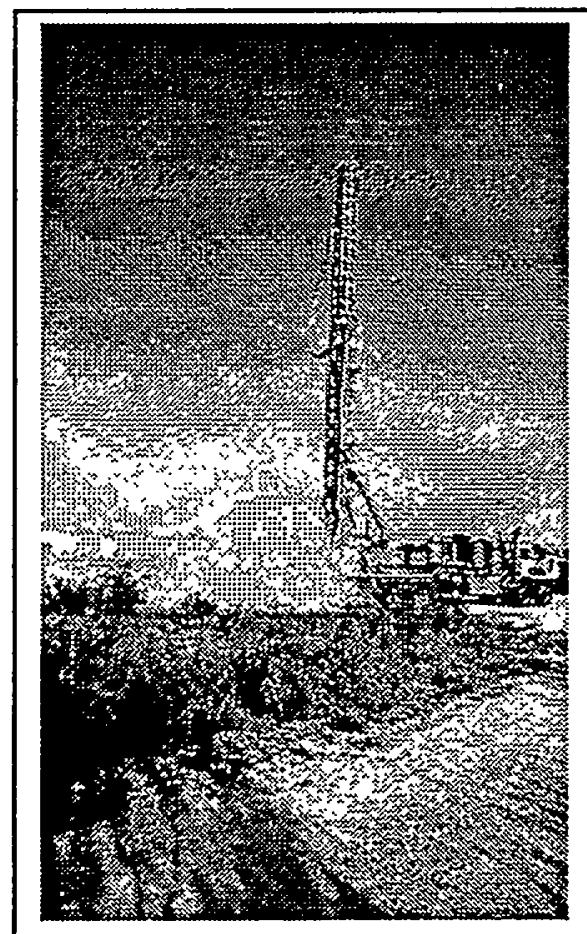

Figure 9a - Air Drilling Test Hole

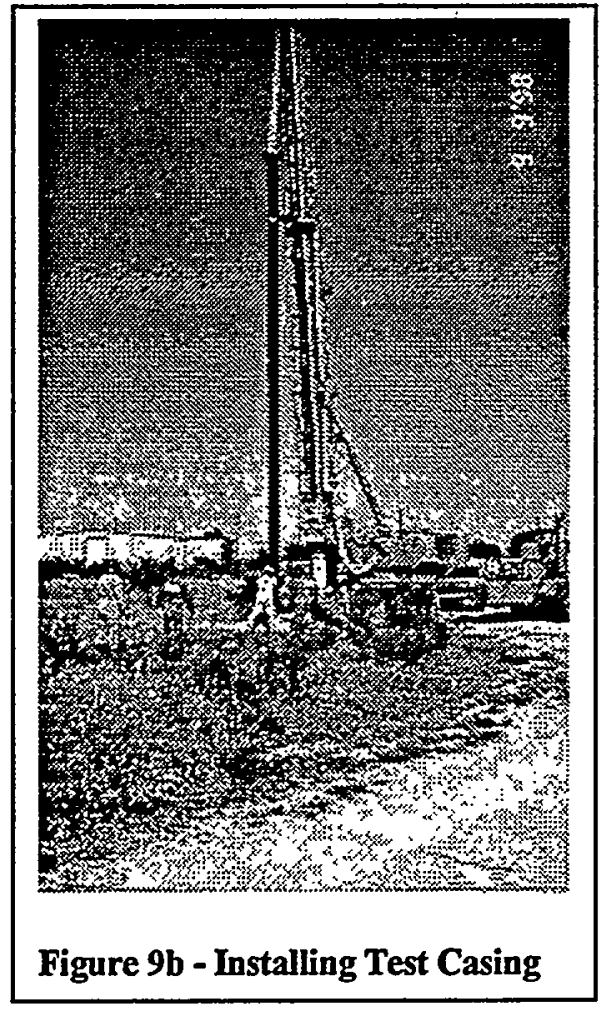

\section{B.) First Field Test at the Midland, TX Facility}

A second BP was fabricated by HES for a full-scale field test. To confirm BP shroud removal, enough pressure had to be applied to the shroud removal piston so deployment could be documented, with the coiled tubing rig pressure gages, at the surface. The bottom end of the BP shroud was equipped with shear pins that were designed to fail when 1200 to $1500 \mathrm{psi}$ of nitrogen gas pressure was applied to the shroud removal piston. This pressure should provide a large enough pressure spike to be seen from the surface, when the BP is set in a well at The Geysers. To test the operation of the BP in an environment that modeled a typical Geysers well, the test was conducted in a $40^{\prime}$ length of 11-3/4", 54\#/ft., steel casing provided by Unocal. The BP was to be set in the casing on coiled tubing using nitrogen gas to remove the shroud and deploy the BP. Ten feet of cement was then to be pumped onto the BP petal basket, again using nitrogen gas to push a wiper and thus the cement through the coiled tubing, as required in our specifications. We initially planned to conduct this test at the HES Dallas/Fort Worth Technology Center located near Carrollton, TX. However, due to our tight schedule and the Tech Center's prior commitments we were required to find an alternate test site. Doug Love, a Halliburton Coiled Tubing Technical Specialist from Midland, TX was able to provide a site for this full scale field verification test. The site was located on HES property located between Midland and Odessa, TX and provided convenient access for HES trucks and equipment.

A "Rat Hole" drill rig was used to air drill a 38' deep hole on the HES site, and install the $40^{\prime}$ test casing in the hole, (see Figures 9a \& 9b). The test casing had a cone welded to the bottom to guide it in hole and to prevent the casing from being cemented in the hole, if the BP did not properly contain the cement. A flange was welded to the top of the casing to secure 
the casing to the stripper on the coiled tubing rig. The BP was unpacked, inspected, and attached to the coiled tubing crossover fitting. As shown in Figure 10, the BP was attached to the crossover fitting below the coiled tubing injector and stripper. The BP was then lowered into the casing and the stripper was attached to the casing flange. Figure 11 shows the final setup for this test bed including the HES coiled tubing, nitrogen, and cement trucks.

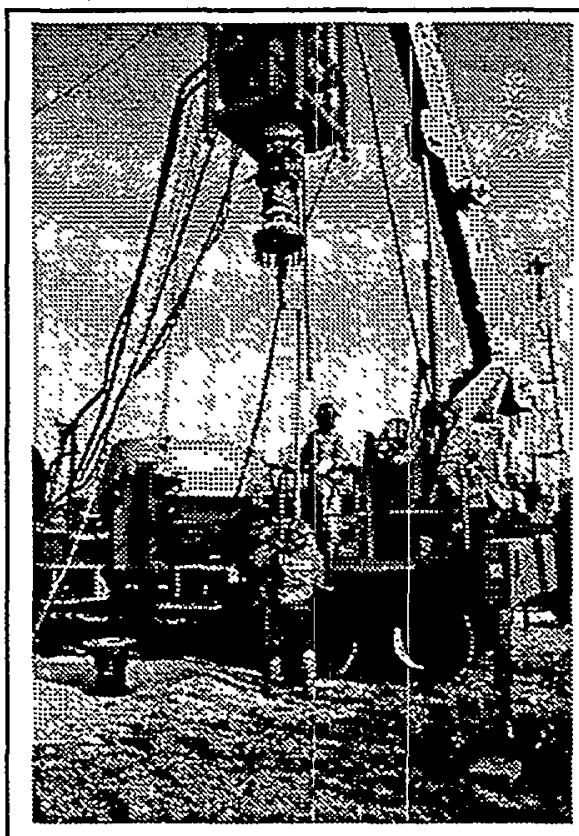

Figure 10 - Attaching BP to Coiled Tubing Crossover Fitting

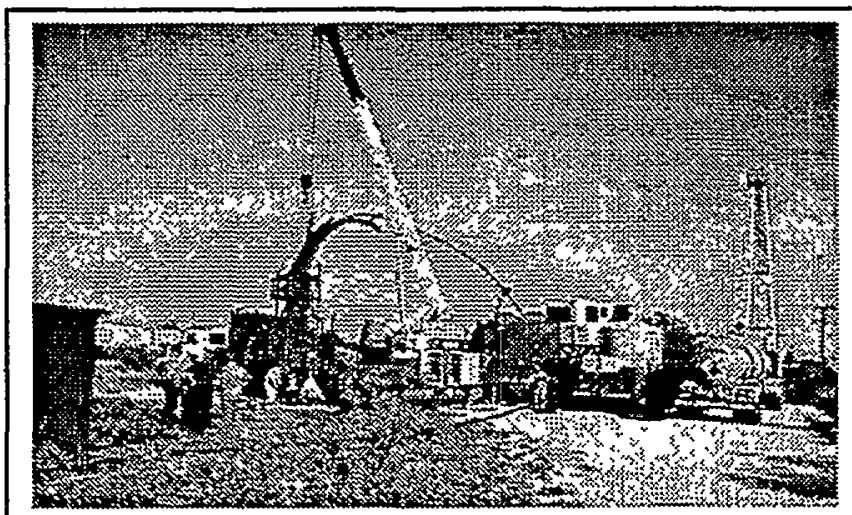

Figure 11 - Final Setup at Midland, TX

The test was conducted on $9 / 10 / 98$. The BP was deployed in the casing, as intended, with nitrogen gas. The shroud shear pins broke at $1297 \mathrm{psi}$ releasing the BP. A shear pin failure pressure spike was recorded on the coiled tubing rig data acquisition system. The remaining gas in the coiled tubing was then vented to the atmosphere through the casing and out an exhaust valve on the stripper. This indicated that the shroud was completely off the BP since the nitrogen gas could only vent from the coiled tubing, in this manner, if the shroud was pushed completely off and the BP was free inside the casing. After the coiled tubing was completely vented, enough cement to produce a $10^{\prime}$ column in the casing and the wiper was placed inside the coiled tubing. The cement was then pushed through the coiled tubing and onto the BP petal basket using nitrogen gas pressure behind the wiper. The wiper did not seat correctly in its catcher, at the end of the coiled tubing. Nitrogen gas therefore flowed around the wiper and into the casing, again venting to the atmosphere through the exhaust valve in the stripper. The wiper design had to be changed to eliminate this problem and meet our requirements for The Geysers casing remediation work.

A plot of the HES data taken with the coiled tubing rig data acquisition system during this test, is shown below in Figure 12. 


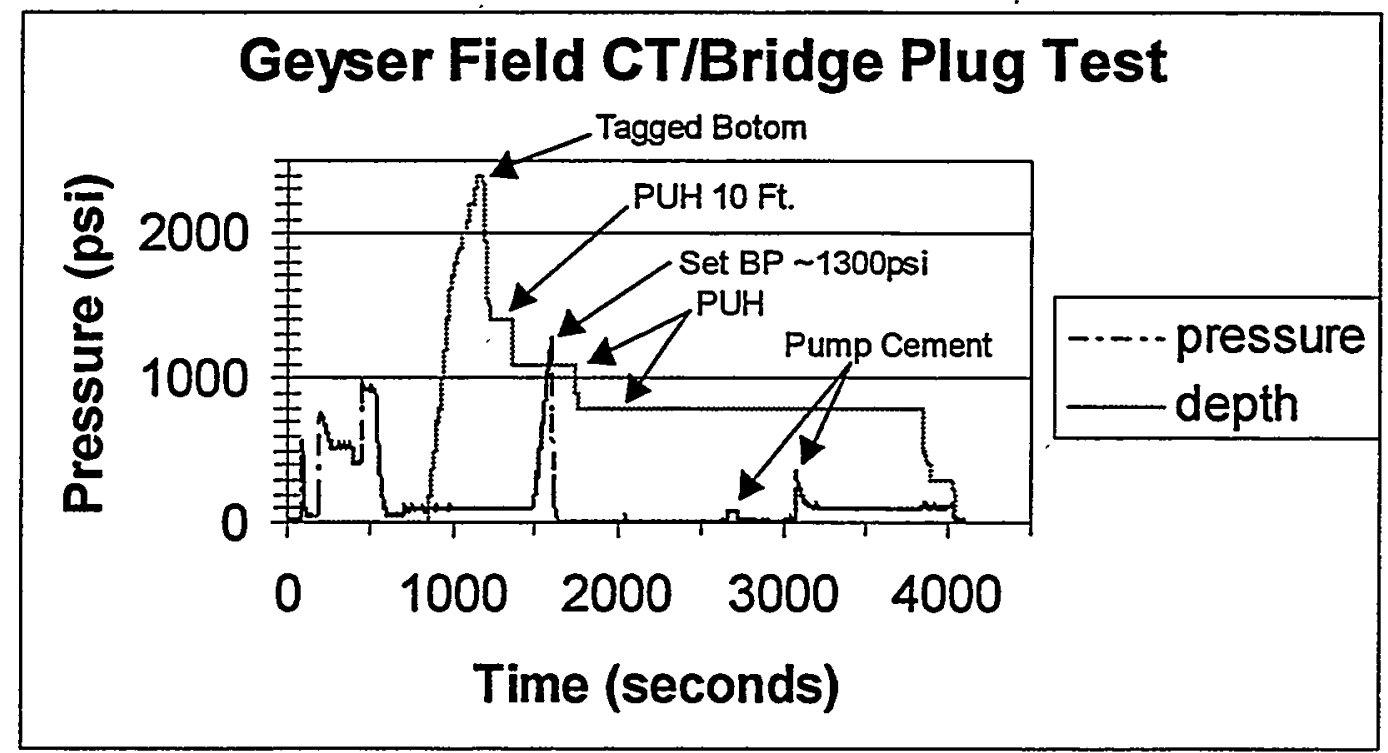

Figure 12 - HES Data from the First Test at Midland

The cement was allowed to cure overnight. Then the casing was rigged, pulled out of the hole, and laid down for dissection and inspection. The cone at the bottom of the casing was torch cut off. Cement was found in the cone indicating a breach of the BP petal

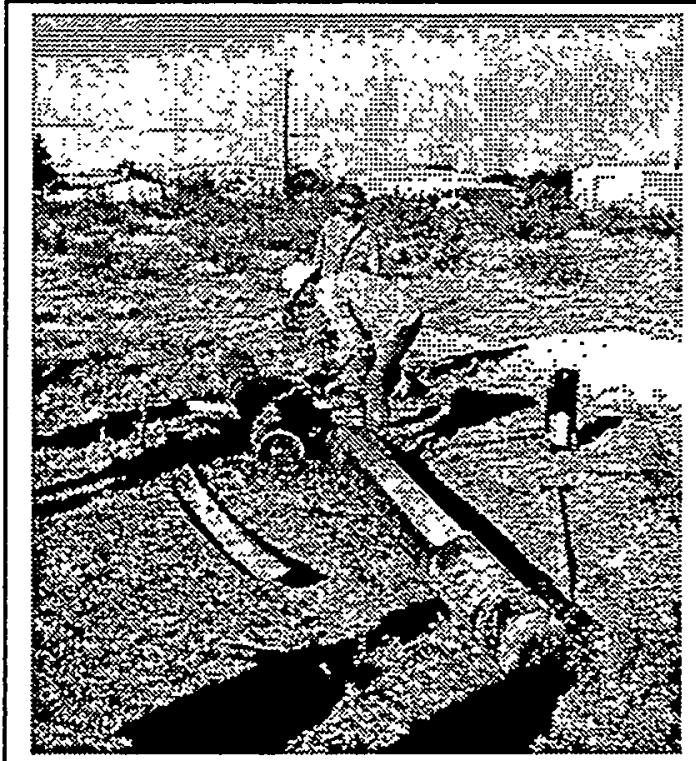

Figure 13 - Cutting Casing After Test

basket. Sectioning of the casing, as shown in Figure 13, revealed that cement filled the casing well above the BP and that the BP petal basket did not support the cement. More than the intended $10^{\prime}$ of cement was pumped inta the casing, but this is a cement volume calibration problem and was not the cause of the BP failure. We continued to cut apart the casing and removed the BP. Examination of the excavated BP, see Figure 14 photograph, revealed that the petal basket petals were twisted, bent, and broken off of the BP. The assumption was that the exhausting nitrogen gas from the $1300 \mathrm{psi}$ shroud removal operation caused enough turbulence in the casing to destroy the petal basket before the cement was pumped. Discussions were held between HES, Unocal and Sandia to arrive at a BP design modification that would eliminate this problem. The selected solution was to only remove enough of the BP shroud, with the high-pressure nitrogen gas, to release the BP and expose the bottom set of dogs. This would allow the petal basket to remain inside the shroud while the nitrogen gas vented from the coiled tubing. After nitrogen venting was complete, the shroud could be pulled 
the rest of the way off with the coiled tubing and thus deploy the remainder of the BP. To verify that this modification would solve the petal basket problem and to verify that the petal basket would indeed support a 10' column of cement, a second test at Midland was planned.

\section{C.) Modification Tests at the Fort Worth Facility}

To verify modifications of the $B P$ in the laboratory, prior to conducting the second fieldtest, several proof tests were completed at the HES facility in Ft. Worth. One modification was to reduce the length of the BP petal basket and make it stronger when deployed. To accomplish this strength increase, the petals were made from thicker material. However, this thick material proved to be too stiff and the basket did not

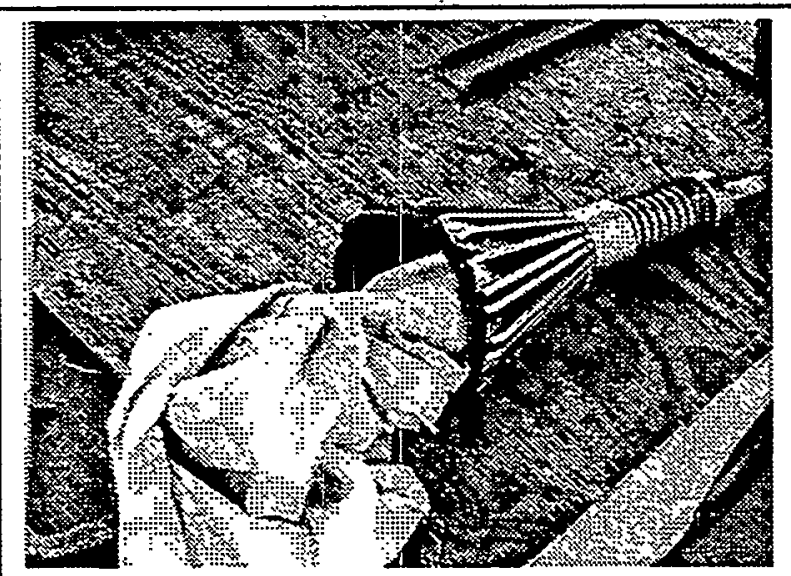

Figure 15 - Petal Basket with Stiffening Bars

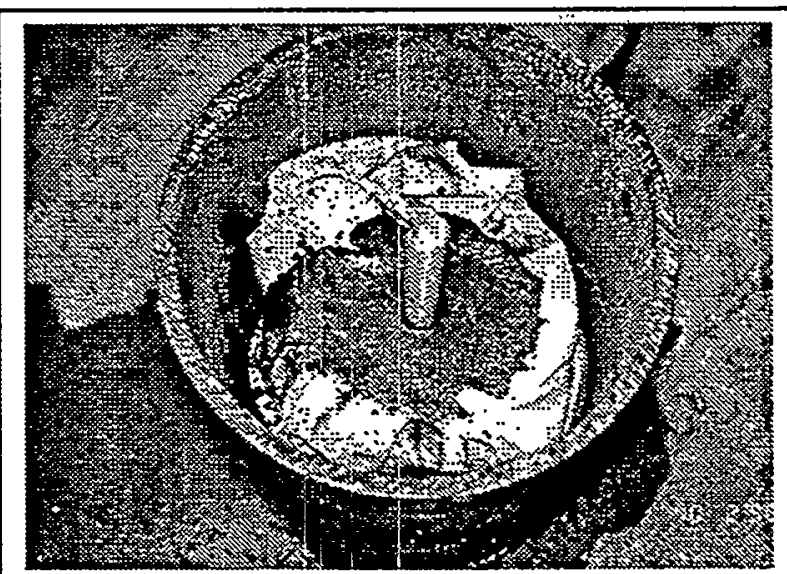

Figure 16 - Cement Containment Test

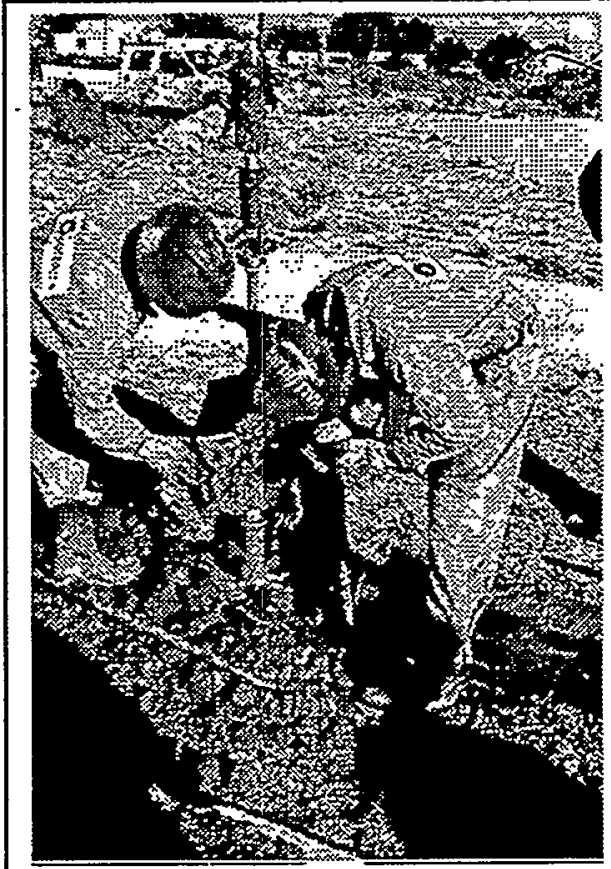

Figure 14 - BP Recovery After Test

deploy properly. The basket was then assembled from the original thickness material, but made shorter in length. This new petal basket design operated successfully in several laboratory proof tests. In addition to modifying the petal basket, a series of stiffening bars, below the petal basket, were added to the BP assembly. These bars act as backup support for the petal basket, if the basket were to fail due to excessive loading, (see Figure 15).

To again verify the cement holding capability of the Nomex cloth covered petal basket, several leak-through tests were conducted. As shown in Figure 16, the Nomex material around the petal basket held the Class $\mathrm{H}$ cement and contained it well enough to prevent any leakage through the petal basket petals. This cement holding proof-test provided us with confidence that the Nomex covered petal basket would contain the $10^{\prime}$ column of cement long enough for the cement to begin to 


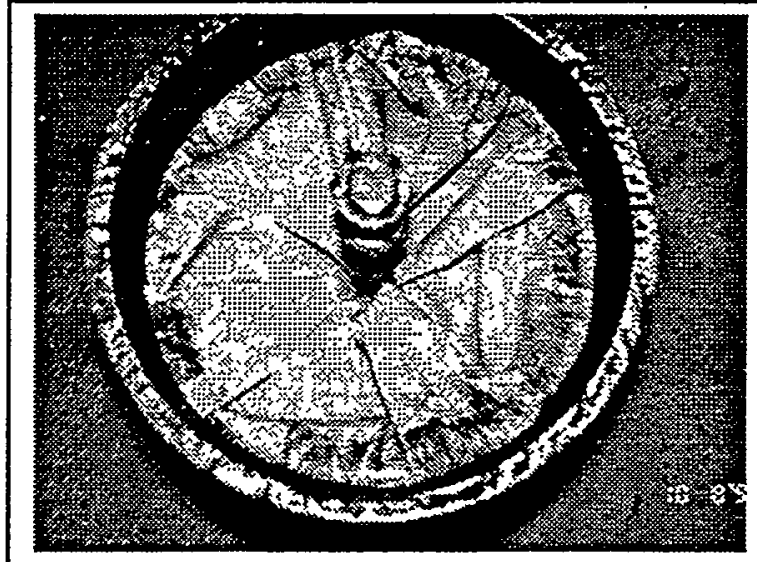

Figure 17 - Final Proof Test

setup. Figure 17 shows the final laboratory proof test verifying correct petal basket deployment with the Nomex cover and backup stiffening bars both in place.

The shroud support/slide tube was reduced in length so the shroud would only move up the slide tube about 12 " and only uncover the bottom dog assembly. The shroud shear pins were again designed to break at 1200 to 1500 psi. Operation of this mechanism was identical to the previous test, and did not require further proof testing. A "redesigned" BP assembly was prepared by HES for a second full-scale field test at Midland.

\section{D.) Second Field Test at the Midland, TX Facility}

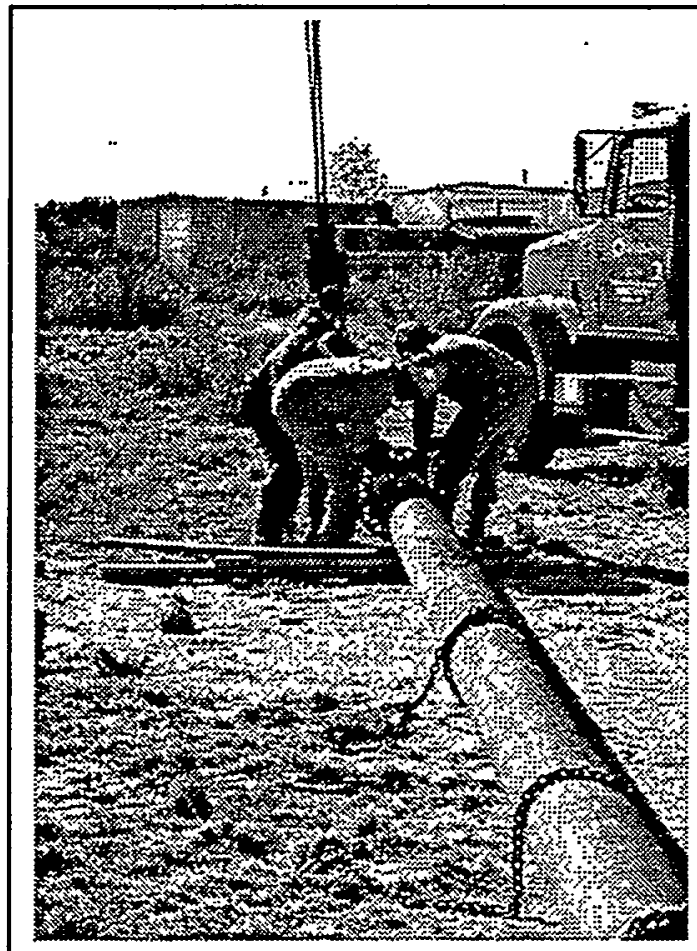

Figure 18 - Flange Installation
The new HES BP was assembled in Ft. Worth and shipped to Midland for the second test. The same test bed hole used previously was uncovered, inspected and readied for this test. A second $40^{\prime}$ long 11$3 / 4^{\prime \prime}$ steel casing, provided by Unocal and modified by HES, was delivered to the site. The new casing again contained a cone at the bottom, but had a threaded collar at the top. A three-foot length of old casing with the old flange was salvaged from the first test and the casing portion was threaded to mate with the collar on the new casing. Figure 18 shows this flange section being installed on the new casing collar. The new assembly was $43^{\prime}$ long from the bottom of the cone to the top of the flange. The casing assembly was then rigged, lifted and placed in the test bed hole, as shown in Figure 19, using the hoist on the coiled tubing rig.

The second test was conducted on 10/14/98. The new BP was assembled for attachment to the coiled tubing. The redesigned shorter shroud slide tube is shown in Figure 20. The BP was attached to the wiper catcher/post test clean out assembly that was in turn connected to the end of the coiled tubing. This assembly was lowered into the test casing and the flanges were secured. The BP was run 


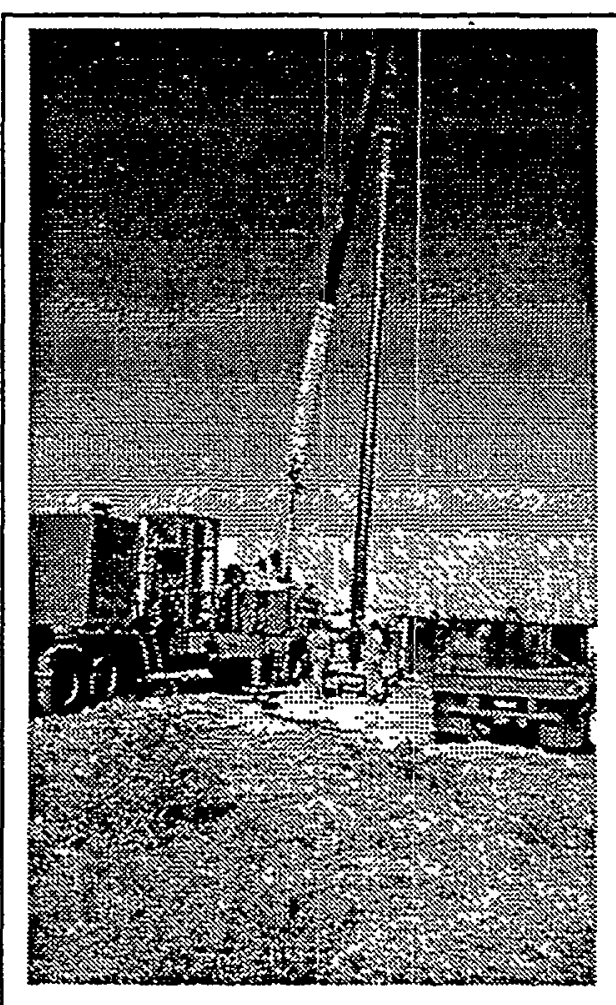

Figure 19 - Casing Assembly

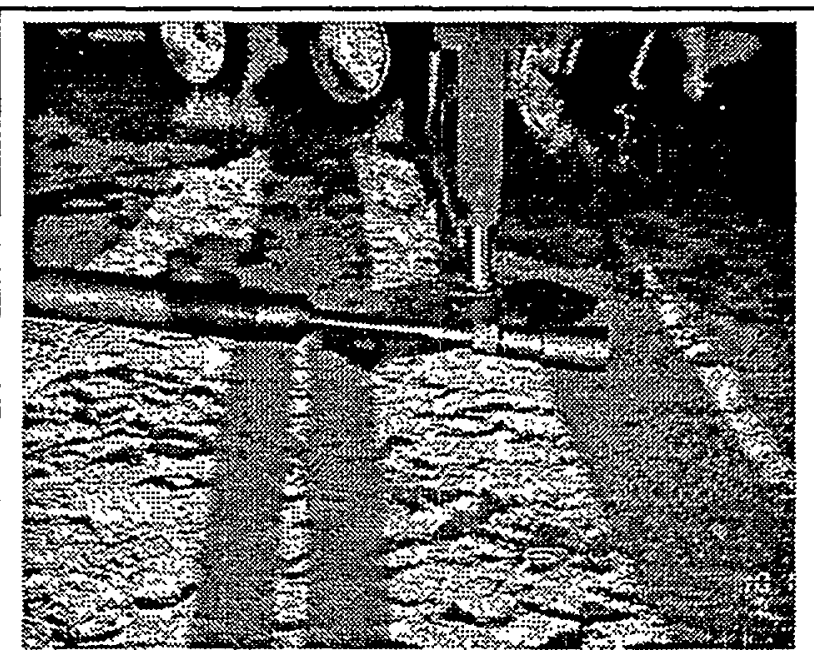

Figure 20 - Shroud with Short Support/Slide Tube

in the casing to tag the cone at the bottom. The bottom was tagged at $32^{\prime}$ as noted on the coiled tubing rig depth indicator. The BP was then pulled up 10 feet to position it for the test. Nitrogen gas was pumped into the BP shroud piston through the coiled tubing. The shear pins broke at approximately $1300 \mathrm{psi}$ and the nitrogen vented from the coiled tubing through the casing as intended. This operation set the bottom dog assembly and the coiled tubing was then pulled up to expose the remaining dogs and the petal basket. The shroud was to be pulled up far enough to break a small wire rope cable attached to the top of the BP and to the bottom of the shroud assembly. This breakaway cable was to provide a weight indication signal on the coiled tubing rig weight indicator, to show that the shroud had been pulled up far enough to completely set the BP. No indication of the 1000-pound load from the breakaway cable was observed on the weight indicator load cell. After pulling up about 11', it was decided that the shroud was off the BP and cement pumping could begin.

Approximately $1.25 \mathrm{bbl}$ of cement (the amount calculated to produce a $10^{\prime}$ column of cement in this casing) was pumped into the coiled tubing and the wiper was inserted behind the cement. The coiled tubing behind the wiper was then pressurized with nitrogen

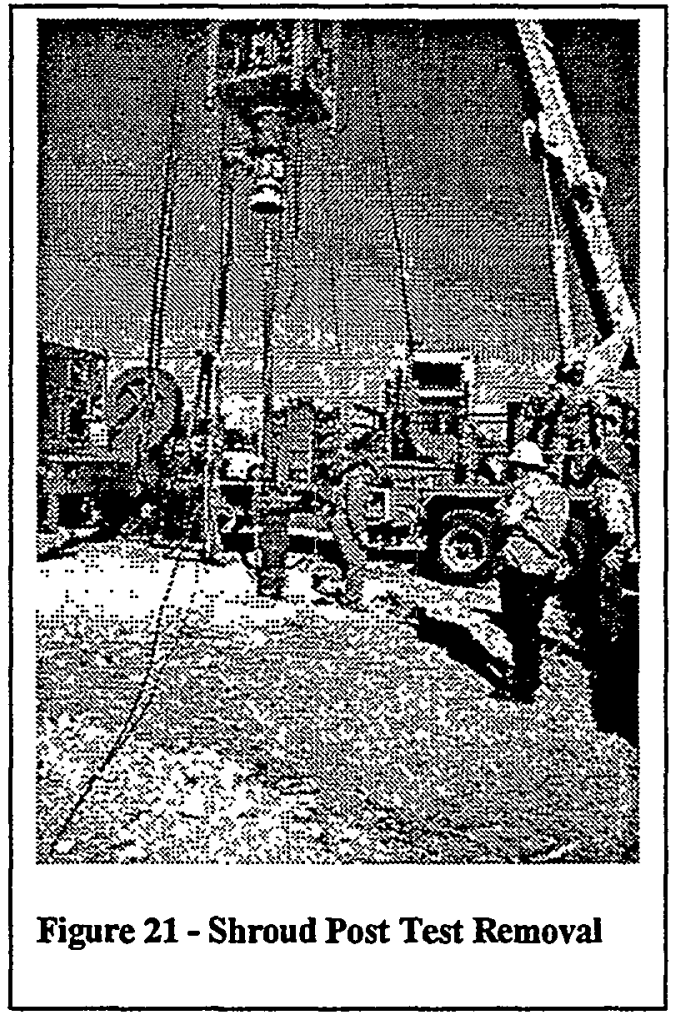


gas to push the cement through the coiled tubing and onto the BP. The cement was pushed with the wiper as intended and after the wiper seated in the catcher assembly the nitrogen was vented from the coiled tubing at the nitrogen truck. The coiled tubing was pulled up to a zero depth indication and the flange bolts were removed. The shroud was then lifted out of the test bed, as shown in Figure 21 above, washed and removed from the wiper catcher assembly. The wiper was then pressurized again, this time to $1900 \mathrm{psi}$ to open the clean out ports on the catcher assembly, so the inside of the coiled tubing could be flushed with water and cleaned.

A plot of the HES data recorded during this test, with the coiled tubing rig data acquisition system, is shown in Figure 22.

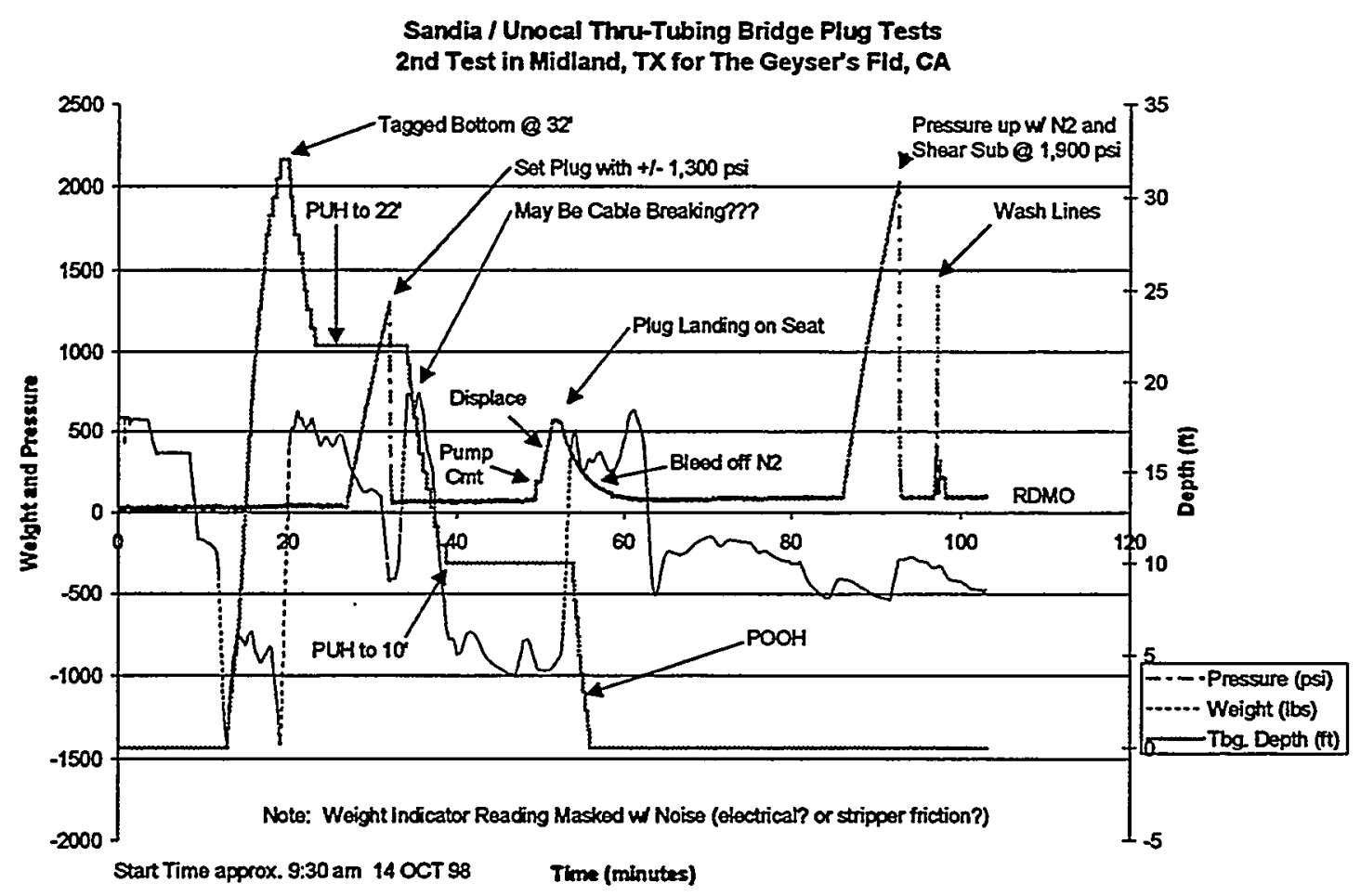

Figure 22 - HES Data from the Second Test at Midland

The cement in the casing was viewed from the surface and measured to be $22^{\prime}-5^{\prime \prime}$ from the casing flange to the top of the cement. This was where it was expected to be if we actually pumped $10^{\prime}$ of cement onto the BP petal basket. We waited overnight for the cement to fully cure. The casing test bed was again rigged and lifted from the hole and positioned on the ground for sectioning. The bottom cone was then cut off the casing, as shown below in Figure 23. No cement was visible in the casing and less than one gallon of diluted cement that filtered through or around the petal basket was visible in the cone. The casing was then cut to expose the deployed BP and cement plug. Figure 24 shows the BP with the $10^{\prime}$ cement plug in position in the sectioned casing. This test was considered a success, except for the breakaway cable problem, and everything functioned 


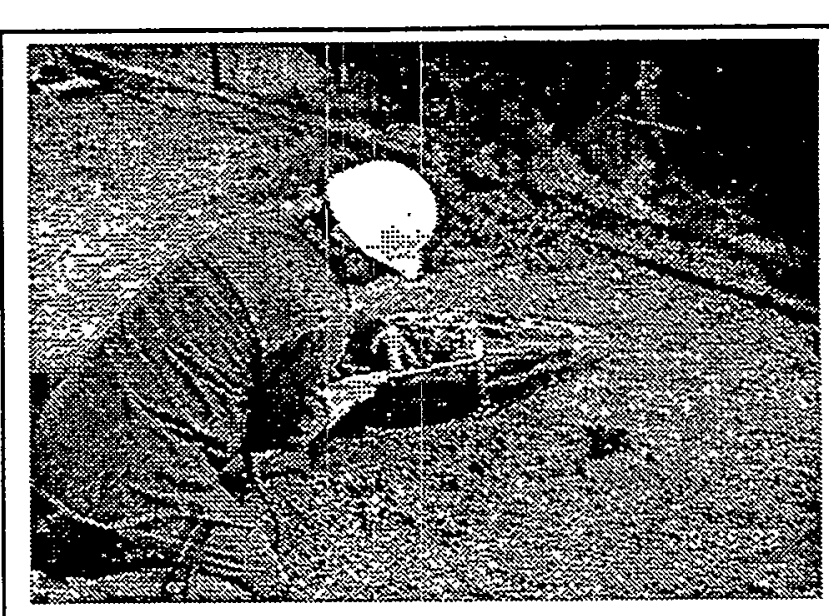

Figure 23 - Cutting Cone as intended. The test also demonstrated that the BP petal basket could support a $10^{\prime}$ column of cement. To determine why the breakaway cable failure was not detected on the coiled tubing rig load indicator, the BP was removed from the test bed. The cement was removed from the top of the BP to expose the breakaway cable. The cable appeared to have pulled out of its clamp on the shroud assembly instead of breaking, see Figure 25. This cable attachment design would have to be changed on future BP assemblies to insure that the cable

will break before pullout can occur. The entire BP assembly was then packaged and returned to the HES Ft. Worth facility for additional post test analysis.

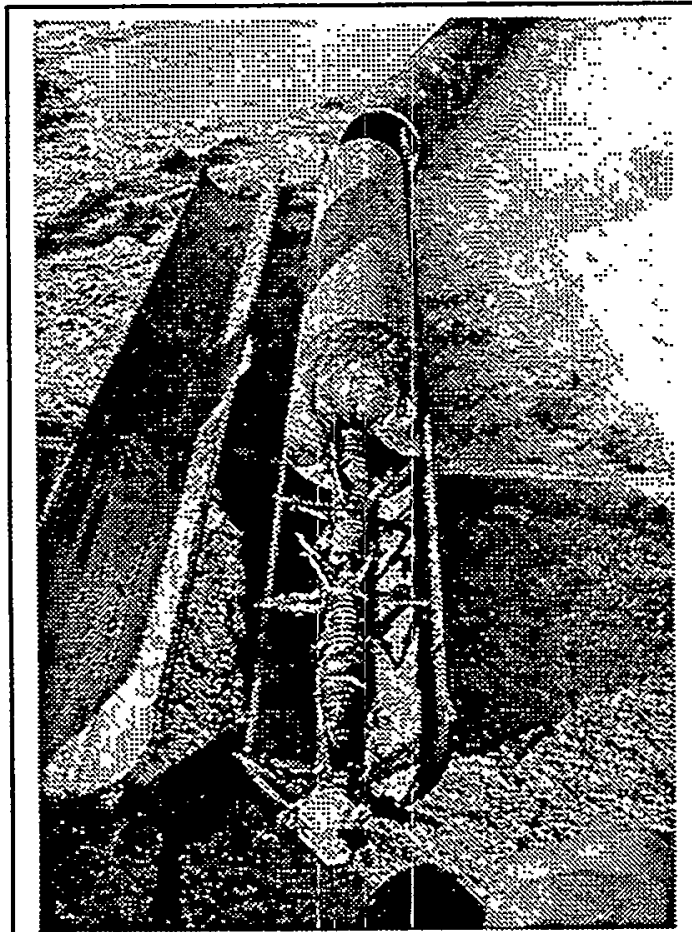

Figure 24 - Sectioned Casing

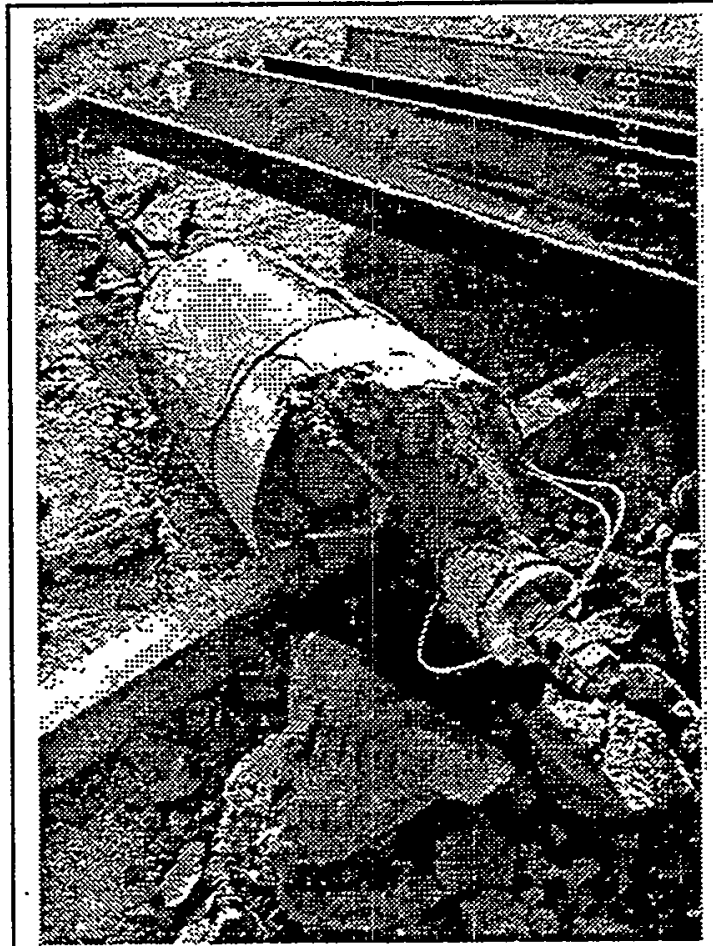

Figure 25 - Break Cable Recovery 


\section{Conclusion}

Through a rapid development and testing program, a HES thru-tubing BP has been modified, tested and certified for use in geothermal well casing remediation applications at The Geysers geothermal field. This BP has been named the Special Application Coiled Tubing Applied Plug (SACTAP). The SACTAP meets or exceeds the technical requirements for this application and can be deployed on coiled tubing and set in a $450^{\circ} \mathrm{F}$ steam filled, non-flowing, well casing, using nitrogen gas. Test results show that up to ten feet of wet cement can safely be placed directly on the SACTAP petal basket. After this initial $10^{\prime}$ column of cement cures, calculations and field experience show ${ }^{3}$ that an additional $20^{\prime}$ of sand and/or up to $190^{\prime}$ of wet cement can safely.be added to the SACTAP to complete the plug and secure the well for casing remediation work or well abandonment. After casing remediation work is completed, the SACTAP can be drilled over, to cut the tips off the support legs on the dogs, and removed. Using the basic GO thru-tubing BP design, SACTAP's can be readily modified, by HES, to accommodate various size casings and could again be adapted for deployment on a wireline, if necessary.

A SACTAP based on this design was procured by Sandia and used, by Unocal, during casing remediation work at The Geysers. The SACTAP functioned as intended during this operation, although other problems resulted in failure of the actual casing remediation work ${ }^{4}$. Future casing remediation efforts that require a bridge plug for milling or other operations can utilize this technology.

The 11-3/4", 54\#/ft steel casing SACTAP has a maximum outside diameter of 3.75 " prior to deployment, is $110^{\prime \prime}$ long, and weighs approximately 200 pounds. A HES drawing of the SACTAP is provided in Appendix A. SACTAP bridge plugs can be purchased directly from HES. The HES contact for procurement is Mr. Jamie Terrell, Manager, Chemical/Physics Laboratory, Halliburton Energy Services, 1100 Everman Parkway, Fort Worth, TX 76101-1936. A six to eight week lead-time is required for fabrication, assembly and delivery of a SACTAP. 


\section{References}

1. GDO Project - "Geysers Deformed Casing Remediation", Proposed Friday 04/03/98 by Baljit Singh, Unocal Corporation and Allan R. Sattler, Sandia National Laboratories.

2. G.E. Staller, D.A. Glowka, J. Gabaldon, P. Gronewald, S.D. Knudsen, D.W. Raymond, J.J. Westmoreland, G.L. Whitlow, J.L. Wise, and E.K. Wright, 1999 "Design, Development and Testing of a Drillable Straddle Packer for Lost Circulation Control in Geothermal Drilling," Sandia Report, SAND99-0819, Sandia National Laboratories, Albuquerque, NM, 87185-1033.

3. Technical data sheet "Determination of Minimum Plug Length," High Pressure Integrity, Inc., 1204 Distributors Row, Harahan, LA 70123, reference internet http://www.hpitools.com/index 3.htm, technical data, plug length, and HES instructions for the Dump Bailer Cement Kit, see section on "Recommended Plug Length".

4. Steve Furry 1999 "The Dog Leg Reamer/Casing Patch Project," GDO Report, Geothermal and Power Operations, Unocal Corporation, Santa Rosa, CA 95401. 


\title{
APPENDIX A
}

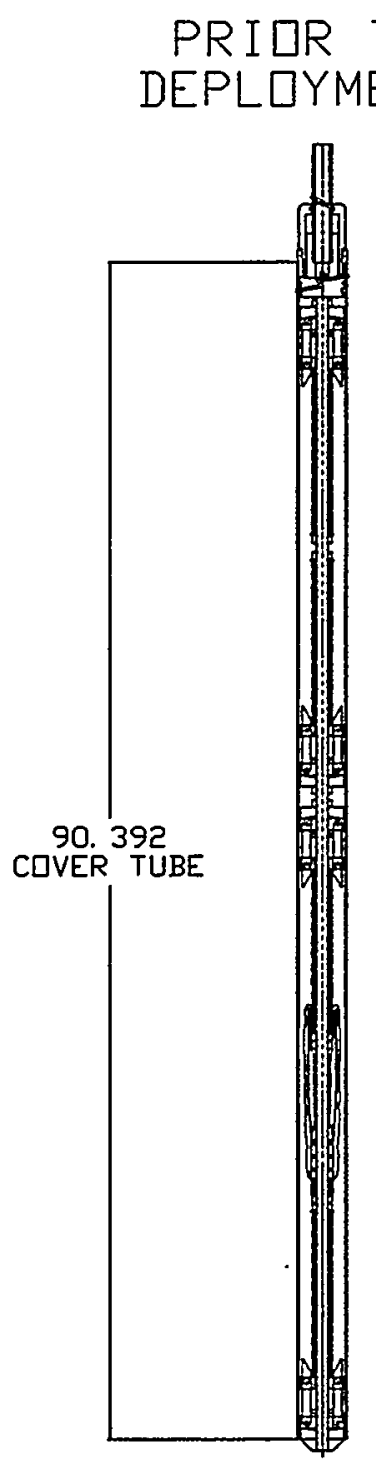

\section{DEPLIYED}

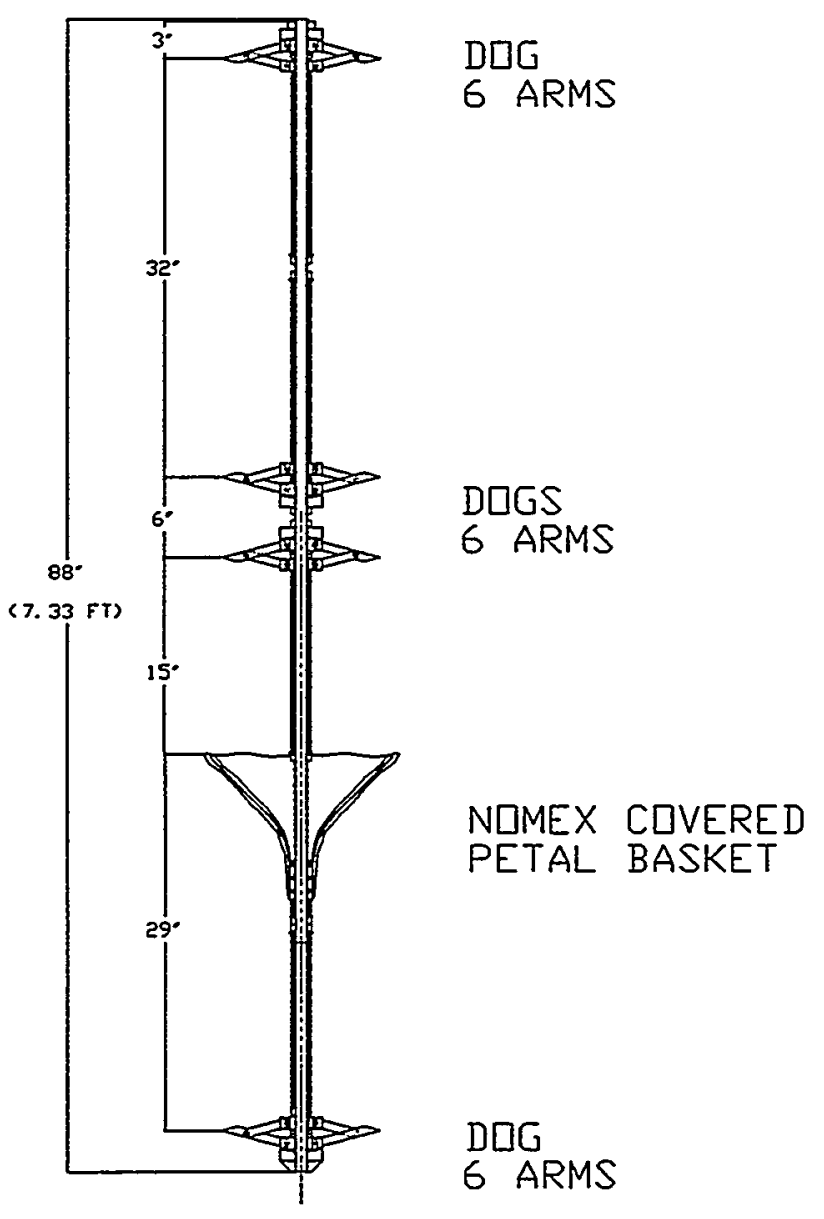

\author{
HES - SACTAP \\ BRIDGE PLUG \\ FOR 11-3/4 CASING
}


APS TECHNOLOGY

Bill Turner, Managing Director

800 Corporate Row

Cromwell, CT 06416

BALLEW TOOL COMPANY

Leon D. Ballew

P.O. Box 361

Cobb, CA 95426

BAKER HUGHES INTEQ

Nic Nickels

2050 W. Steele Lane, Suite C-1

Santa Rosa, CA 95403

BAROID DRILLING FLUIDS, INC.

Gene Polk

Manager, Customer Service

2220 First Street, NW

Albuquerque, NM 87102-1041

BOART LONGYEAR COMPANY

Roger Magee

P.O. Box 1000

Dayton, NV 89403

BOART LONGYEAR COMPANY

John Mastor, General Manager

Contracting Services

P.O. Box 27314

Salt Lake City, Utah 84127-0314

BOART LONGYEAR COMPANY

Patrick "Paddy" J. Langan

Product Manager

P O Box 27314

Salt Lake City, Utah 84127-0314

CALENERGY

Alex Schriener, Jr.

950 W. Lindsey Road

Calipatria, CA 92233
CALENERGY

Don Condie

950 W. Lindsey Road

Calipatria, CA 92233

CALPINE CORPORATION

Marc Steffen

10350 Socrates Mine Road

Middletown, CA 95461

CAITHNESS RESOURCES, INC.

Gordon G. Gollan

6111 Kelso Valley Road

Weldon, CA 93283

COSO OPERATING CO.

John Gastineau

900 N. Heritage Dr., Bldg. D

Ridgecrest, CA 93555

WILLIAM D'OLIER

Geothermal Energy Consultant

310 Hume Lane

Bakersfield, CA 93309-2427

DOWELL SCHLUMBERGER

Bob Fagan, WCS

Laboratory Manager, Western Division 6090 Greenwood Plaza Blvd.

Englewood, CO 80111

DOWELL SCHLUMBERGER

Bud Frederick

Engineering \& Marketing Manager

P O Box 81437

DOWELL SCHLUMBERGER

Ron Wilson

Cement Cell Leader

P O Box 81437

Bakersfield, CA 93380-1437 
DRILL COOL SYSTEMS, INC.

Elwood Champness

Tom Champness

627 Williams Street

Bakersfield, CA 93305

ENP CAPITAL RESOURCES, INC.

David A. Glowka, Director

811 Sussex Drive

Austin, TX 78745

EPOCH WELLSITE SERVICES, INC.

Steve Appleton

5880 District Blvd. \#10

Bakersfield, CA 93313

E V I OIL TOOLS

McALLISTER

Bob Johnson

P O Box 1824

Palm Springs, CA 92263

EV I WEATHERFORD

Joe Turk

1000 Church Road

Rio Vista, CA 94571

E V I WEATHERFORD

Tom Bailey

515 Post Oak Blvd.

Houston, TX 77027

GEO HILLS ASSOCIATES

James B. Combs

2395 Catamaran Drive

Reno, NV 89509-5731

GEOTHERMAL DEVELOPMENT

ASSOCIATES

G. Martin Booth III

251 Ralston Street

Reno, NV 89503
GEOTHERMAL RESOURCE GROUP

Bill Rickard

P O Box 11898

40201 Sagewood Drive

Palm Desert, CA 92255

GEOTHERMEX, INC.

James W. Lovekin

Manager of Field Operations

5221 Central Avenue, Suite 201

Richmond, CA 94804

GWB CONSULTANTS

Gary W. Batcheller

704 Sage Brush Road

Yukon, OK 73099

HALLIBURTON ENERGY SERVICES

Jamie Terrell, Manager, Chemistry Lab

1100 Everman Parkway

Fort Worth, TX 76140

HALLIBURTON ENERGY SERVICES

Doug Love, Coil Tubing Tech Specialist 4000 N. Big Spring

Midland, TX 79705

HALLIBURTON ENERGY SERVICES

Don Rogers, Team Coordinator

P.O. Box 3746

Odessa, TX 79760-3746

HALLIBURTON ENERGY SERVICES

John Messerschmidt

Field Technical Advisor

P O Box 80118

Bakersfield, CA 93380-0118

J\&R ENERGY ASSOCIATES, INC.

Nyla Jones

1514 Lupine Road

Healdsburg, CA 95448 
LAYNE CHRISTENSEN CORP.

Brian Edwards

P.O. Box 3077

Salt Lake City, UT 84130-0777

LIVESAY CONSULTANTS, INC.

Bill Livesay

126 Countrywood Lane

Encinitas, CA 92024

M-I DRILLING FLUIDS CO.

Tom Heinz

6301 Seven Seas Avenue

Bakersfield, CA 93308

NABORS DRILLING USA, INC.

Ron Cleveland

3919 Rosedale Highway

Bakersfield, CA 93308

NADET INSTITUTE

Peter H. Smeallie

600 Woodland Terrace

Alexandria, VA 22302

NOVATEK

David S. Pixton

2185 South Larsen Pkwy

Provo, UT 84606

OCEAN DRILLING PROGRAM

Eugene C. Pollard, Jr.

Operations Superintendent

Texas A\&M University Research Park

1000 Discovery Drive

College Station, TX 77840

OXBOW POWER SERVICES, INC.

Walter R. (Dick) Benoit

Resource Manager

9790 Gateway Drive, Suite 220

Reno, NV 89511
PAJARITO ENTERPRISES

John Rowley

3 Jemez Lane

Los Alamos, NM 87544

SMITH DRILLING AND COMPLETIONS

Mike Florence

3101 Steam Court

Bakersfield, CA 93308

SMITH INTERNATIONAL, INC.

John Campbell

P O Box 60068

Houston, TX 77032

SOUTHERN METHODIST UNIVERSITY

David D. Blackwell

Department of Geological Sciences

Dallas, TX 75275

STATE OF CALIFORNIA CALIFORNIA ENERGY COMMISSION

Pablo Gutierrez

Energy Technology Development Division

Research and Development Office

$15169^{\text {th }}$ Street, MS-43

Sacramento, CA 95814-5512

THERMASOURCE, INC.

Louis E. Capuano, Jr.

P.O. Box 1236

Santa Rosa, CA 95402

THERMASOURCE, INC.

Jim Hanson

P.O. Box 1236

Santa Rosa, CA 95402

TONTO DRULLING SERVICES, INC.

Larry Pisto

2200 South 4000 West

Salt Lake City, UT 84126 
TONTO DRILLING SERVICES, INC.

Nguyen Do

2200 South 4000 West

Salt Lake City, UT 84126

TRANS PACIFIC GEOTHERMAL

Tsvi Meidav

111 Broadway, Suite 300

Oakland, CA 94607

TWO-PHASE ENGINEERING

AND RESEARCH, INC.

Douglas Jung, P.E.

3209 Franz Valley Road

Santa Rosa, CA 95404

UNIVERSITY OF UTAH

Energy \& Geoscience Institute

Dennis L. Nielson, Ph.D.

Department of Civil and

Environmental Engineering

423 Wakara Way, Suite 300

Salt Lake City, UT 84108

UNOCAL GEOTHERMAL

Steve Furry

1300 North Dutton Avenue

Santa Rosa, CA 95401

UNOCAL GEOTHERMAL

Rodney Bray

1300 North Dutton Avenue

Santa Rosa, CA 95401

UNOCAL CORPORATION

Michael E. Utt, P.E.

Technology \& Operations Support

14141 Southwest Freeway

Sugar Land, Texas 77478-3435

U.S. DEPARTMENT OF ENERGY

Paul Grabowski

Office of Geothermal Technologies, EE-12

1000 Independence Avenue, SW

Washington, DC 20585
U.S. DEPARTMENT OF ENERGY

Allan Jelacic

Geothermal Division, EE-12

1000 Independence Avenue SW

Washington, DC 20585

U.S. DEPARTMENT OF ENERGY

Lew W. Pratsch

Office of Geothermal Technologies, EE-12

1000 Independence Avenue, SW

Washington, DC 20585

U.S. DEPARTMENT OF ENERGY

Marshall J. Reed, Program Manager

Geothermal Reservoir Technology

Office of Geothermal Technologies, EE-12

1000 Independence Avenue, SW

Washington, DC 20585

\section{Internal Distribution:}

MS-0706 J. K. Linn (6113)

MS-1033 M. R. Prairie (6211)

MS-1033 S. D. Knudsen (6211) 10 copies

MS-1033 G. E. Staller (6211) 10 copies

MS-1033 A. R. Sattler (6211) 5 copies

MS-9018 Central Technical Files, 8940-2

MS-0899 Technical Library, (4916) 2 copies

MS-0612 Review \& Approval Desk, (4912) for DOE/OSTI 